\title{
Craniofacial Forms among Three Dominant Ethnic Groups of Gombe State, Nigeria
}

\author{
Formas Craneofaciales entre Tres Grupos Étnicos Dominantes del Estado de Gombe, Nigeria
}

\author{
M. B. Maina; O. Mahdi \& G. G. Kalayi
}

\begin{abstract}
MAINA, M. B.; MAHDI, G. G. \& KALAYI, G. G. Craniofacial forms among three dominant ethnic groups of Gombe state, Nigeria. Int. J. Morphol., 30(1):211-216, 2012.

SUMMARY: Anthropometric measurements such as cranial and facial forms provide essential information that can be used added provide in orofacial surgery and in diagnostic comprehension between patient and normal populations. There is no published literature about the types of head and face shapes in Fulani, Tangale and Tera ethnic groups of Nigeria. Hence, this study was undertaken to document the various cranial and facial forms of these ethnic groups residing in Gombe region of North-Eastern Nigeria. Head length, head width, head circumference, face length and face width were measured and the cephalic and prosopic indices calculated in a total of 300 subjects ( 150 males and 150 females). Results analyzed placed all males of the three ethnic groups in dolicocephalic head group with mean cephalic indices lower than 74.9, while all females to mesocephalic head group with mean cephalic indices between the range of 75-79.9. On the basis of face shapes, The Fulani and Tera males were found to belong to hyperleptoprosopic group, while the Tangale and Tera females to leptoprosopic group with prosopic indices over 95 and between the ranges of 90-94.9, respectively. Therefore, the findings revealed that all males and females of the three ethnic groups share close similarities in head types and some variations in face types. Furthermore, variation of head and face shapes from this study exists with those of other studies within and outside Nigeria.
\end{abstract}

KEY WORDS: Cephalic index; Prosopic index; Head types; Face types

\section{INTRODUCTION}

Anthropometric measurements such as cranial and facial forms provide background knowledge of health status, further development and effect of factors such as ethnicity; race etc. on the human head and face dimensions. It provides good technique through which head and face forms can be ascertain. On international standard humans head shape are either be dolicocephalic, brackiocephalic, mesocephalic or hyperbrakicephalic and human face shapes are either be hypereuriprosopic, euriprosopic, mesoprosopic, leptoprosopic or hyperleptoprosopic (Williams et al., 1995; Panero, 1979). These different head and face types are affected by ethnic, ecological, biological, geographical, racial, gender, age and nutritional factors (Okupe et al., 1984; Tuli et al. 1995; Radovic et al., 2000; Rajlakshmi et al., 2001; Golalipour et al., 2003).

Head and face shapes are also useful in paediatrics, forensic medicine, plastic surgery, oral surgery and diagnostic comprehension between patient and normal populations (Williams et al., 1995). People that have doliocephalic head types usually have otitis media less often than those that have brachycephalic head type (Stolovitsky \& Todd, 1990; Oladipo et al., 2010). And it has been reported that individuals with Apert's syndrome are hyperbrachycephalic (Cohen \& Kreiborg, 1994; Oladipo et al., 2010 ).

Fulani, Tangale and Tera are Nigerian tribes that are found not only in Gombe state but in many parts of Nigeria; little anthropometry literature exist on the Fulani, while no literature exist on the Tangale and the Tera, in view of documented studies on the effects of ethnicity and race on head and face dimensions this study was design to determine the head and face shapes present in adult males and females of these three tribes of Gombe state origin.

\section{MATERIAL AND METHOD}

Subjects. This study was conducted on normal randomly selected Fulanis, Tangales and Teras residing in Gombe State 
region of North-Eastern Nigeria from March to June 2011. A total of 300 subjects (50 males and 50 females from of each tribe) with ages ranging from 18 to 40 years were used. Prior and informed consent was obtained from the subjects, and the study was carried out after obtaining clearance from the ethical committee of Federal Medical Centre Gombe, Nigeria.

Cephalic and Prosopic measurements. Cephalic and Prosopic measurements were taken after careful palpation with subjects in a relaxed condition with head in the anatomical position using standard anatomical landmarks (Lobo et al., 2005). Using a spreading calliper two head measurements (cephalic length and cephalic width), two face measurements (prosopic length and prosopic width) and head circumference were measured:

- Cephalic length: length from Glabella to Inion.

- Cephalic width: length between parietal eminences.

- Prosopic length: length from nasion to Gnation.

- Prosopic width: Lenght between zygomatic arches.

- Head circumference: length of a measuring tape placed from a point slightly above the glabella, supercilliary arch and superior margin of the external acoustic meatus round via the inion and back to the point above the glabella.
Cephalic and prosopic indices will be determined by:

- Cephalic index $(\mathrm{CI})=$ Head width/ head height $\mathrm{x} 100$

- Prosopic index $(\mathrm{PI})=$ face length/face width $\mathrm{x} 100$

Depending upon the ranges of these indices, head and face types are classified according to Williams et al., 1995 and Panero, 1979 (Table I).

\section{RESULTS}

The means of cephalic indices obtained from this study in Fulani, Tangale and Tera were 71.4, 74.8 and 73.3, respectively in males while females presented with $76.4,76.8$ and 75.9 , respectively. The total means of cephalic indices in male and female subjects of all the tribes were 73.2 and 76.4 , respectively (Table I). The means of prosopic indices obtained from this study in Fulani, Tangale and Tera were 95.2, 92.1 and 94.1, respectively in males while females presented with 100.8, 92.6 and 102.4, respectively. Total means of cephalic indices in male and female population of all the tribes were 93.7 and 98.1 , respectively. The distribution of means of head and face shapes are depicted in Table II. Intra tribal assessment of the distribution of head and face shapes from this study is depicted in Table III. Table IV show the comparison of Cephalic and prosopic index with other population.

\begin{tabular}{llll}
\hline & Range & Scientific term & Meaning \\
\hline Head type & $<74.9$ & Dolicocephaly & "Long head type" \\
& $75-79.9$ & Mesocephaly & "Medium head type" \\
& $80-84.9$ & Brachycephaly & "Short broad head type" \\
& $85-89.9$ & Hyperbrachycephaly & "very short broad head type" \\
Face type & $<79.9$ & Hypereuriprosopic & "very short broad face type" \\
& $80-84.9$ & Europrosopic & "short broad face type" \\
& $85-89.9$ & Mesoprosopic & "medium or intermediate face type" \\
& $90-94.9$ & Leptoprosopic & "Long narrow face type" \\
& $>95$ & Hyper Leptoprosopic & "Very long narrow face type" \\
\hline
\end{tabular}

Table II. Means of cephalic indices (CI) and Prosopic indices (PI) in males (M) and females (F) among the tribes

\begin{tabular}{lllllllll}
\hline Parameters & $\begin{array}{lllll}\text { Fulani }(\mathrm{M}) \\
\mathrm{n}=50\end{array}$ & $\begin{array}{l}\text { Fulani }(\mathrm{F}) \\
\mathrm{n}=50\end{array}$ & $\begin{array}{l}\text { Tangale }(\mathrm{M}) \\
\mathrm{n}=50\end{array}$ & $\begin{array}{l}\text { Tangale }(\mathrm{F}) \\
\mathrm{n}=50\end{array}$ & $\begin{array}{l}\text { Tera }(\mathrm{M}) \\
\mathrm{n}=50\end{array}$ & $\begin{array}{l}\text { Tera }(\mathrm{F}) \\
\mathrm{n}=50\end{array}$ & $\begin{array}{l}\text { Male Mean } \\
\text { Total }(\mathrm{n}=150)\end{array}$ & $\begin{array}{l}\text { Female Mean } \\
\text { Total }(\mathrm{n}=150)\end{array}$ \\
\hline CI & 71.4 & 76.4 & 74.8 & 76.8 & 73.3 & 75.9 & 73.2 & 76.4 \\
PI & 95.2 & 100.8 & 92.1 & 92.6 & 94.1 & 102.4 & 93.7 & 98.1
\end{tabular}


Table III. Intra tribal percentage distribution of head shapes

\begin{tabular}{|c|c|c|c|c|c|c|c|}
\hline & Parameters & Fulani (M) & Fulani (F) & Tangale (M) & Tangale (F) & Tera $(\mathrm{M})$ & Tera $(F)$ \\
\hline & & $\mathrm{n}=50$ & $\mathrm{n}=53$ & $\mathrm{n}=52$ & $\mathrm{n}=67$ & $\mathrm{n}=50$ & $\mathrm{n}=50$ \\
\hline Head ypes & Dolicocephy & $78 \%$ & $41.50 \%$ & $51.92 \%$ & $37.31 \%$ & $66 \%$ & $46 \%$ \\
\hline & Mesocephaly & $18 \%$ & $35.84 \%$ & $32.69 \%$ & $26.86 \%$ & $32 \%$ & $28 \%$ \\
\hline & Brachycephaly & $2 \%$ & $13.20 \%$ & $13.46 \%$ & $23.88 \%$ & $2 \%$ & $22 \%$ \\
\hline & Hyperbrachycephaly & $2 \%$ & $9.43 \%$ & $1.92 \%$ & $11.94 \%$ & $0 \%$ & $4 \%$ \\
\hline Face types & Hypereuriprosopic & $4 \%$ & $0 \%$ & $1.9 \%$ & $5.97 \%$ & $2 \%$ & $0 \%$ \\
\hline & Euriprosopic & $2 \%$ & $3.77 \%$ & $7.69 \%$ & $14.92 \%$ & $2 \%$ & $6 \%$ \\
\hline & Mesoprosopic & $12 \%$ & $7.54 \%$ & $28.84 \%$ & $17.91 \%$ & $20 \%$ & $6 \%$ \\
\hline & Leptoprosopic & $32 \%$ & $18.86 \%$ & $32.69 \%$ & $25.37 \%$ & $32 \%$ & $10 \%$ \\
\hline & Hyperleptoprosopic & $50 \%$ & $69.81 \%$ & $28.84 \%$ & $35.82 \%$ & $44 \%$ & $78 \%$ \\
\hline
\end{tabular}

\section{DISCUSSION}

Intra and inter group analyses placed all males of the three ethnic groups in the dolicocephalic head group (CI <74.9), while all females in the mesocephalic head group (CI between 75.9 and 76.8) (Table II). On the bases of face shapes, Fulani males and females are hyperleptoprosopic (PI > 95); Tangale males and females are both leptoprosopic (PI between 90 and 94.9); Tera males are leptoprosopic (PI 94.1) while their females are hyperleptoprosopic (PI 102.4) (Table II). However, total mean prosopic indices in all males (PI 93.7) and females (PI 98.1) of the three tribes placed them in the leptoprosopic and hyperleptoprosopic groups respectively. These findings contradict our previous study in north-eastern Nigerian population (Raji et al., 2010) where mean of males and females cephalic and prosopic indices placed them all in dolicocephalic head group and hyperleptoprosopic face group, respectively. This could be attributed to ethnic factor, which has been shown to affect head dimensions (Golalipour \& Heydari, 2004, 2005; Bayat \& Ghanbari, 2010), because, in this study we restricted our subjects to Fulani, Tangale and Tera of Gombe state region of NorthEastern Nigeria, while in our previous study we collected data from North-Eastern Nigerians irrespective of their tribes, which means the tribes in this region may individually have different head dimensions.

Intra tribal analyses from these findings revealed that dolicocephaly is the dominant head type $(>37 \%)$ while hyperbrachycephaly is the rarest head type $(<10 \%)$ in all the subjects, except Fulani males where both brachycephalic and hyperbrachycephalic head types are the most rare $(2 \%$ each) (Table III). Hyperleptoprosopic face type was found to be the dominant face type among all the tribes (> 35\%) except Tangale males whose dominant face type is leptoprosopic $(32.69 \%)$. While the most rare face type is hypereuriprosopic in all the tribes $(<8 \%)$ except in Fulani males where euriprosopic face type is the rarest $(2 \%)$ and Tangale males where both euriprosopic and hypereuriprosopic face types are the most rare (2\% each). Regarding the dominant head type, these findings are supported by a study carried out by Bharati et al. (2001) which concludes that head forms are dolicocephalic in tropical zones and brachycephalic in temperate zones. It also agrees with the work of Garba et al. (2008) in Maiduguri metropolis that reported the dominant head type in newborns to be dolicocephalic. The cephalic and prosopic indices from this study is agreed by some studies and contradicted by some studies (Table IV).

Anthropological studies based on racial changes have determined that people from Africa, India, Australia, central part of Europe and North America are dolicocephalic; The head shapes of peoples in the Pacific Ocean are of the brachycephalic type, while in the Middle East, Russia and central part of Europe are mesocephalic and most people leaving along the borders of the Atlantic Ocean are of the mesocephalic type (Chamella, 1997; Golalipour et al., 2003). Cephalic and prosopic indices from our study is agreed by some studies and contradicted by some studies (Table III). Variations in these indices between and within populations can be due to a complex interaction between genetic and environmental factors (Kasai et al., 1993). Moreover, ecological, biological, geographical, racial, gender and age factors have been reported to influence bodily dimensions (Okupe et al., 1984; Tuli et al., 1995; Rajlakshmi et al., 2001; Golalipour et al., 2003). 
Table IV. Comparison of Cephalic and prosopic index with other population

\begin{tabular}{|c|c|c|c|c|}
\hline Place and/People & Reference & Age & Cephalic Index & Prosopic Index \\
\hline Nigeria/Ogoni tribe males & Oladipo et al. 2009 & $25-45$ & 111.18 & Not included \\
\hline Nigeria/Ogoni tribe females & Oladipo et al. 2009 & $25-45$ & 75.09 & Not included \\
\hline Nigeria/Ibibio tribe males & Oladipo et al. 2010 & $18-83$ & 79.85 & Not included \\
\hline Nigeria/Ibibio tribe females & Oladipo et al. 2010 & $18-83$ & 78.36 & Not included \\
\hline Nigeria/Ogbia tribe males & Eroje et al. 2010 & $2-18$ & 73.68 & Not included \\
\hline Nigeria/Ogbia tribe females & Eroje et al. 2010 & $2-18$ & 72.24 & Not included \\
\hline Nigeria/kanuri males & Garba et al. 2008 & Newborn & 70.03 & 83.77 \\
\hline Nigeria/kanuri females & Garba et al. 2008 & Newborn & 77.15 & 82.84 \\
\hline Nigeria/Babur males & Garba et al. 2008 & Newborn & 73.60 & 80.74 \\
\hline Nigeria/Babur females & Garba et al. 2008 & Newborn & 77.23 & 81.03 \\
\hline Nigeria/Jos & Umar et. al 2006 & $12-36$ & 78.90 & Not included \\
\hline Nigeria/Hausa & Umar et al. 2011 & $13-30$ & 75.85 & Not included \\
\hline Nigeria/Yorubas & Umar et al. 2011 & $13-30$ & 79.52 & Not included \\
\hline Northeastern Nigeria Males & Raji et al. 2010 & $19-35$ & 71.90 & 99.39 \\
\hline Northeastern Nigeria females & Raji et al. 2010 & $19-35$ & 73.92 & 97.54 \\
\hline Iran/Fars tribe & Golalipour 2006 & $17-20$ & 84 & Not included \\
\hline North Iran/Fars Males & Jahanshahi et al. 2008 & $17-20$ & Not included & 88.22 \\
\hline North Iran/Fars females & Jahanshahi et al. 2008 & $17-20$ & Not included & 84.48 \\
\hline Iran/Turkmans & Golalipour et al. 2003 & Newborn & 77.00 & 80.93 \\
\hline Iran/Fars & Golalipour et al. 2003 & Newborn & 77.97 & 72.95 \\
\hline North Iran/Turkman Males & Jahanshahi et al. 2008 & $17-20$ & Not included & 87.25 \\
\hline North Iran/Turkman females & Jahanshahi et al. 2008 & $17-20$ & Not included & 81.48 \\
\hline India/Punjabi students males & Mahajan et al. 2010 & $17-23$ & 81.34 & Not included \\
\hline India/Punjabi males & Mahajan et al. 2010 & $17-23$ & 85.75 & Not included \\
\hline Indian/Gujurat males & Shah \& Jadhav 2004 & $17-23$ & 80.42 & Not included \\
\hline Indian/Gujurat females & Shah \& Jadhav 2004 & $17-23$ & 81.20 & Not included \\
\hline Chile/Mapuches & Del Sol 2005 & $17-83$ & 80.4 & Not included \\
\hline Nigeria/Fulani males & Present study & $18-40$ & 71.4 & 95.2 \\
\hline Nigeria/Fulani females & Present study & $18-40$ & 76.4 & 100.8 \\
\hline Nigeria/Tangale males & Present study & $18-40$ & 74.8 & 92.1 \\
\hline Nigeria/Tangale females & Present study & $18-40$ & 76.8 & 92.6 \\
\hline Nigeria/Tera males & Present study & $18-40$ & 73.3 & 94.1 \\
\hline Nigeria/Tera females & Present study & $18-40$ & 75.9 & 100.4 \\
\hline
\end{tabular}

The findings from this study reveal that all males and females of the three ethnic groups share close similarities in head shapes and some variations in face shapes. Furthermore, variation of head and face shapes from this study exist with other studies within and outside Nigeria.
ACKNOWLEDGEMENTS. We wish to record our appreciation to Aisha Umar Yaro, Abdulkadir Halliru, Hajara Isah Jibrin, Maisamari Chailau Abare, Maryam, the staffs and students of Gombe State University for their support and assistance during this study. 
MAINA, M. B.; MAHDI, G. G. \& KALAYI, G. G. Formas craneofaciales entre tres grupos étnicos dominantes del estado de Gombe, Nigeria. Int. J. Morphol., 30(1):211-216, 2012.

RESUMEN: Las medidas antropométricas tales como las formas craneales y faciales ofrecen importantes informaciones que son relevantes que pueden ser usadas en la cirugía orofacial y en la comprensión diagnóstica entre los pacientes y las poblaciones normales. No hay literatura publicada sobre los tipos de formas de la cabeza y la cara de los grupos étnicos Fulani, Tangale y Tera de Nigeria. Por lo tanto, este estudio se realizó para documentar las diversas formas craneales y faciales de estos grupos étnicos que residen en la región de Gombe, en el Noreste de Nigeria. Fueron medidos, longitud de la cabeza, ancho de la cabeza, circunferencia de la cabeza, longitud de la cara y ancho de la cara y se efectuaon los cálculos cefálicos y faciales en un total de 300 sujetos ( 150 hombres y mujeres 150). Los resultados analizados en los hombres Fulani, Tangale y Tera determinaron que éstos eran dolicocéfalos con una media de índices cefálicos menor que 74,9, mientras que las mujeres eran mesocefálicas, con índices cefálicos en el rango de 75 a 79,9. Con respecto a los tipos de cara, los hombres Fulanis y Tera se presentaron con índice prosopo en más del 95, por lo tanto, colocándolos en el grupo de cara hiperleptoprosópico, mientras que las mujeres Tangales y Tera presentaron en el índice prosopo un intervalo de 90 a 94,9, por lo tanto, colocándolas en el grupo leptoprosopo . Los resultados revelaron que los hombres y mujeres de los tres grupos étnicos comparten similitudes en los tipos de cabeza y algunas variaciones en los tipos de cara. Por otra parte, existe variación de las formas de cabeza y cara de este estudio con otros estudios realizados dentro y fuera de Nigeria.

PALABRAS CLAVE: Índice cefálico; Índice prosopo; Tipos de cabeza; Tipos faciales.

\section{REFERENCES}

Abolhasanzadeh, A. \& Farahani, M. R. Standard international classification of head shapes of 22-24 years old in Tehran. $J$. of Research in Medicine, 26:281-5, 2003.

Bayat. P. B. \& Ghanbari. A. Comparison of the Cranial Capacity and Brain Weight of Arak (Central Iran) with other Subgroups of Iranian Population. Int. J. Morphol., 28:323-6, 2010.

Bharati, S.; Som, S.; Bharati, P. \& Vasulu, T. S. Climated and head form in India. Am. J. Hum. Biol., 13:626-34, 2001

Chamella, M. Biological anthropology. Translated to Persian (Farsi) by Nadri A. $1^{\text {st }}$ Ed. Tehran, Gostar Publisher, 1997.

Cohen, M. M. Jr. \& Kreiborg, S. Cranial size and configuration in the Apert syndrome. J. Craniofac. Genet. Dev. Biol., 14:15362, 1994.

Del Sol, M. Cephalic index in a group of mapuche individuals in the IX Región of Chile. Int. J. Morphol, 25:241-6, 2005.

Eroje, M. A.; Fawehinmi, H. B.; Jaja, B. N. \& Yaakor, L. Cephalic Index of Ogbia Tribe of Bayesla State. Int. J. Morphol., 28:38992, 2010

Garba, S. H.; Numan, A. I. \& Mishara, I. G. Craniofacial classification of normal newborns in Maiduguri metropolis, Nigeria. Int. J. Morphol., 26:407-10, 2008.

Golalipour, M. J. \& Haidari, K. Effect of the Ethnic Factor on Cranial Capacity and Brain Weight of Male Newborns in Northern Iran. Neuroembryology and Aging, 5:146-8, 2005.

Golalipour, M. J. The variation of head shapes in 17-20 years old native Fars male in Gorgan-North of Iran. Int. J. Morphol, 24:187-90, 2006.
Golalipour, M. J.; Haidari, K.; Jahanshahi, M. \& Frahani, M. R. The shapes of head and face in normal male newborns in SouthEast of Caspian Sea (Iran-Gorgan). Anat. Soc. India, 52:2831,2003 .

Jahanshahi, M.; Golalipour, M. J. \& Heidari, K. The effect of ethnicity on facial anthropometry in Northern Iran. Singapore Med. J., 49:940-3, 2008.

Kasai, K.; Richard, L. C. \& Brown, T. Comparative study of craniofacial morphology in Japanese and Australian aboriginal population. Hum. Biol., 65:821-34, 1993.

Lobo, S. W.; Chandrashekhar, T. S. \& Kumar, S. Cephalic index of Garung Community of Nepal-An anthropometric study. Kathmandu Univ. Med. J., 3:263-5, 2005.

Mahajan, A.; Khurana, B. S.; Seema \& Batra, A. P. S. The Study of Cephalic Index in Punjabi Students. J. Punjab Acad. Forensic Med. Toxicol., 10:24-6, 2010.

Okupe, R. F.; Cooker, O. O. \& Gbajumo, S. A. Assessment of fetal biparital diameter during normal pregnancy by ultrasound in Nigerian women. Br. J. Obstet. Gynaecol., 99:629-32, 1984.

Oladipo, G. S.; Olotu, J. E. \& Suleiman, Y. Anthropometric studies of cephalic indices of the Ogonis in Nigeria. Asian J. Med. Sci., 1:15-7, 2009.

Oladipo, G. S.; Okoh, P. D. \& Isong, E. E. Anthropometric Studies of Cephalic Length, Cephalic Breadth and Cephalic Indices of the Ibibios of Nigeria. Asian J. Med. Sci., 2:104-6, 2010.

Radovic’, Z.; Muretic’', Z`.; Nemirovskij, V. \& Gaz`i-C`oklica, V. Craniofacial Variations in a South Dalmatian Population. Acta Stomatol. Croat., 34:399-403, 2000. 
Raji, J. M.; Garba, S. H.; Numan, A. I.; Waziri, M. A. \& Maina, M. B. Morphological evaluation of head and face shapes in a North-Eastern Nigerian population. Aust. J. Basic Appl. Sci., 4:3338-41, 2010.

Rajlakshmi, C. H.; Shyamo Singh, M.; Bidhumukhi, T. H. \& Chandramani Singh L. Cephalic index of foetuses of manipuri population - A Baseline study. J. Anat. Soc. India, 50(1):13-6, 2001.

Shah, G.V. \& Jadhav, H.R. The study of cephalic in students of Gujarat. J. Anat. Soc. India. 53(1):25-6, 2004.

Stolovitsky, J. P. \& Todd, N. W. Head shape and abnormal appearance of tympanic membranes. Otolaryngol. Head Neck Surg., 102:322-5, 1990.

Tuli, A.; Choudhry, R. ;Agarwal, S.; Anand, C. \& Gary, H. Correlation between craniofacial dimensions and foetal age. J. Anat Soc. India. 44(1):1-12, 1995.

Umar, M. B. T.; Ojo, A. S.; Asala, S. A. \& Hambolu, J. O. Comparison of Cephalometric indices between the Hausa and Yoruba ethnic groups of Nigeria. Res. J. Med. Sci., 5:83-9, 2011.

Umar, M. B. T.; Singh, R. \& Shugaba, A. I. Cephalometric indicies among nigerians. J. Appl. Sci., 6:939-42, 2006.

Williams, P.; Dyson, M.; Dussak, J. E.; Bannister, L. H.; Berry, M. M.;Collins, P. \& Ferguson, M. W. J. Skeletal system. In: Gray's Anatomy. $38^{\text {th }}$ Edn. London, Elbs with Churchill Livingston, 1995. pp.

\section{Correspondence to: Mahmoud Bukar Maina Department Of Human Anatomy College of Medical Sciences Gombe State University Tudun Wada Quarters, PMB 127 Gombe NIGERIA}

Mobile: +2348066011112

Email: mahmoudbukar@yahoo.com

Received: 18-07-2011

Accepted: 03-10-2011 